\title{
An Inquiry into the Nature and Causes of Nigeria's Rapid Urban Transition
}

\author{
Kyle Farrell $^{1,2}$ (D)
}

Published online: 31 May 2018

(C) The Author(s) 2018

\begin{abstract}
Owing to the dramatic pace and scale of its transformation, Nigeria is considered Africa's next urban giant. Between 1960 and 2010, Nigeria added approximately 62.5 million inhabitants to its urban population, with forecasts to 2050 projecting an additional 226 million. As Nigeria forges ahead into the next chapter of its urban transition, there is an unmet need to take stock of past experiences, identify trends, and speculate on future growth trajectories. Taking advantage of recently available datasets from the United Nations and the Africapolis Project, this paper launches an inquiry into the nature and causes of Nigeria's rapid urban transition between 1960 and 2010. It disaggregates urbanization into its individual components of urban growth and calculates their contributions to the overall urban increment. Several notable findings are highlighted. Nigeria, which is considered a late urbanizer, is currently in the accelerated stage of its urban transition and is projected to enter the terminal stage by 2030. Urban natural population increase has been the dominant component of urban growth in the post-colonial period and will likely continue to be so in the immediate future. Despite this, policies aimed at stemming rural to urban migration appear to have been the preferred mechanism for lessening the pressures posed by the contemporary urban transition, suggesting a potential policy mismatch.
\end{abstract}

Keywords Nigeria - Urban transition · Urbanization curve $\cdot$ Rapid urbanization · Rapid urban growth $\cdot$ Components of urban growth

\section{Kyle Farrell}

krfar@kth.se

1 Division of Urban and Regional Studies, KTH Royal Institute of Technology, Drottning Kristinas Vag 30, Stockholm, Sweden

2 Department of Economics, Harvard University, 1805 Cambridge Street, Cambridge, MA, USA 


\section{Introduction}

Nigeria, which is home to Africa's largest population, is currently undergoing one of the most dramatic urban transformations in history. Following independence in 1960, Nigeria has added approximately 62.5 million inhabitants to its urban population; with forecasts to 2050 projecting an additional 226 million (United Nations 2014). Owing to the dramatic pace and scale of its transformation, Nigeria is anticipated to be Africa's next urban giant.

This paper is premised on the concept of the urban transition, which posits that as a country develops, it undergoes a transformation from a society that is predominantly rural to one that is predominantly urban (Skeldon 1990). The progression of the urban transition is best illustrated through the urbanization curve, which navigates three stages: an initial stage reflecting a predominantly agricultural society with the majority of the population dispersed throughout the rural countryside, to an accelerated stage reflecting a structural transformation of society and a shift in the concentration of the population toward urban areas, and to a final terminal stage reflecting a predominantly industrial society with the majority of the population concentrated in dense urban areas (Northam 1975; Mulligan 2013). ${ }^{1}$ As the African country set to experience the largest increase in urban population over the coming decades, Nigeria represents a rather insightful case study in which to launch an inquiry into the nature and causes of its rapid urban transition.

Nigeria is ranked 152 out of 188 countries on the United Nations Human Development Index and has remained in the "Low Human Development" category since the establishment of the report (United Nations 2016). It currently has approximately $46 \%$ of its population living below the poverty line, nearly two thirds lacking access to adequate sanitation, an average life expectancy of 53 years, and an average per capita GDP of USD 5900 (World Bank 2017). Although urbanization is often associated with higher incomes, increased productivity and overall improvements in one's standard of living, the unprecedented pace and scale of the contemporary urban narrative unfolding in developing countries means that these outcomes are not guaranteed (Annez and Buckley 2009; Quigley 2009; Glaeser 2013). While urbanization is believed to have a role in the social and economic development of a country, this is only realized when the benefits that accrue from agglomeration economies outweigh the urban diseconomies (Turok and McGranahan 2013; Glaeser and Xiong 2017). All too often, however, governments are unaware of the dynamics underpinning the urbanization process, resulting in misaligned policies and poorly targeted interventions. Needless to say, effective management of the urban transition becomes a critical aspect of development. Taking this as the point of departure, the objective of this paper is to take stock of past experiences, identify trends, and speculate on future growth trajectories. It aims to contribute by putting forward a more nuanced account of Nigeria's rapid urban ascent, in hopes of providing insight for managing the urban transition in a more strategic way.

\footnotetext{
${ }^{1}$ In today's developed countries, the transition has largely been completed, with the majority of the population urban (Beall et al. 2010). Whereas developing countries, most of which are currently in the accelerated stage of their urban transition, exhibit potential for future growth.
} 
Taking advantage of recently available datasets from the United Nations and the Africapolis Project, ${ }^{2}$ this paper examines Nigeria's urban transition between 1960 and 2010. It disaggregates urbanization into its individual components of urban growth (rural to urban migration, urban natural population increase, and reclassification of rural areas as urban) and calculates their contributions to the overall urban increment. Several notable findings are highlighted. Nigeria, which is considered a late urbanizer, is currently in the accelerated stage of its urban transition and is projected to enter the terminal stage by 2030 . Urban natural population increase has been the dominant component of urban growth during the post-colonial period and will likely continue to be so in the immediate future. Despite this, policies aimed at stemming rural to urban migration appear to have been the preferred mechanism for lessening the pressures posed by the contemporary urban transition, suggesting a potential policy mismatch.

The paper has been structured as follows: "Caveats, Materials, and Methods" provides some brief notes of caution and an overview of the materials and methods, "History and Trends of the Urban Transition in Nigeria" provides a historical account of Nigeria's urban transition accompanied by some stylistic trends, "The Components of Urban Growth" summarizes the results, and "Discussion" discusses the findings against the backdrop of policy before concluding.

\section{Caveats, Materials, and Methods}

Given the complexity of the urban transition in developing countries, it is prudent to begin by pointing out some areas of common confusion and misconception. Firstly, it is necessary to distinguish between the processes of urbanization and urban growth; the former of which refers to the proportion of the population living in urban areas as opposed to rural areas, and the latter referring to the absolute number of people living in urban areas (Davis 1965; Fox 2011). Secondly, both urbanization and urban growth are underpinned by what the United Nations refers to as the components of urban growth: namely, rural to urban migration, urban natural population increase, and reclassification of rural areas as urban (Kasarda and Crenshaw 1991; Chen and Valente 1998; United Nations 2001). Finally, although urbanization and urban growth occur hand in hand, there are certain circumstances in which urban growth can occur without urbanization. ${ }^{3}$ If careful consideration is not taken, such misconceptions can result in severe policy implications.

Another area of concern has to do with the availability of quality data. This hinges on the documentation of detailed statistical records and a common definition of what it means to be urban. In terms of the former, this is dependent on the capacity of the statistical offices, which tends to vary by

\footnotetext{
The Africapolis project consists of a comprehensive and standardized geospatial database on urban dynamics in Africa. It uses demographic sources, satellite, and aerial imagery and other recognized cartographic sources to inventory all urban agglomerations over 10,000 inhabitants in western Africa.

${ }^{3}$ This is especially important in the case of Africa, where at times rural growth has outpaced urban growth, resulting in an increase in the absolute number of people living in urban areas (urban growth), but with no corresponding increase in the proportion of the population that is urban as opposed to rural (urbanization).
} 
country. As for the latter, unfortunately, no universal definition exists to date, with definitions varying between countries and in some instances across different periods in time within a country. ${ }^{4}$

In the case of Nigeria, a settlement is classified as urban if it exceeds a population threshold of 20,000 inhabitants; this was revised upwards from a previous definition of 5000 inhabitants that existed between 1951 and 1962 (World Bank 2016). Unfortunately, Nigeria's census data has been riddled with inconsistencies over the years and is considered to be of questionable quality. Owing to the use of population indicators to determine the allocation of military and political resources (including representative seats in parliament), national population counts have been accused of being inflated (MoriconiEbrard et al. 2016). This political manipulation led to the cancelation of the census results in $1961^{5}$ and again in 1973, leaving Nigeria with a total of only five population censuses: 1951-1953, 1963, 1991, 2006, and 2011. Fortunately, through modern demographic accounting methods and geospatial mapping techniques, recent efforts have been made to retroactively adjust these counts and generate more detailed population tables based on consistent 10-year intervals (see United Nations 2014; OECD 2017). Although these approaches will never replace a comprehensive census count, such attempts to enhance the quality of existing data are praiseworthy, offering new opportunities to explore historical trends. With United Nations and OECD Africapolis datasets considered the best available population estimates in Western Africa to date, this paper will rely on a combination of these sources. Where necessary, supplementary datasets are turned to in order to further enrich the findings.

To empirically examine the changing nature of Nigeria's urban transition, this paper employs a number of quantitative techniques that are commonplace in development economics; namely, demographic accounting methods, spatial analysis and statistical analysis. Quantitative approaches to knowledge production have been favored over alternatives, as they are considered to offer a higher degree of objectivity and generalizability (Bryman 2012).

\section{History and Trends of the Urban Transition in Nigeria}

With the urban transition having largely completed in most countries throughout North America, Europe, and South America, the urban transition today is almost entirely confined to countries in Asia and Africa. These two regions are projected to account for nearly $90 \%$ of urban population growth by 2050 (United Nations 2014). Nigeria, which belongs to the club of countries that have been dubbed late urbanizers, is the African country poised to experience the largest increase in urban population; making it a particularly fascinating case.

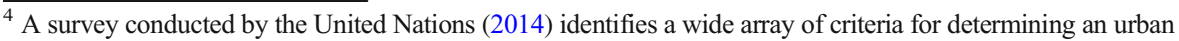
settlement: administrative criteria, population thresholds, population densities, proportion employed in nonagricultural sectors, and the presence of infrastructure and amenities. In some cases, a combination of criteria is used.

${ }^{5}$ The canceled population census in 1961 was replaced by a new census conducted again in 1963.
} 


\section{A Brief History of Nigeria's Urban System}

The contemporary history of Nigeria can ultimately be divided into three periods: the pre-colonial period (before 1854), the colonial period (1854-1960), and the postcolonial period (1960 to date). During the pre-colonial period, the majority of Nigeria's population was scattered throughout the country, with nomadic tribes grazing the land and practicing a predominantly subsistence lifestyle. Early settlements during this time began to appear in the Northern region, comprising the great Hausa Kingdoms and the Kanem-Bornu Empire (Ayedun et al. 2011). These settlements were located along the Trans-Saharan trade route connecting North Africa and West Africa, eventually growing into large trading posts and serving as commercial hubs to facilitate the trade of goods and services (Oduwaye 2015). Kano, Katsina, and Zaria are examples of important trading posts that still exist today. As a result of Yoruba colonization, additional trading settlements began to sprout up in the southwest, further enriching Nigeria's complex system of trading economies (Bloch et al. 2015a). Former Yoruba trading posts include: Ibadan, Ijebu-Ode, and Ife.

The arrival of the colonial period, around the middle of the nineteenth century, disrupted Nigeria's existing settlement hierarchy (Mabogunje 1968). With resource extraction as the main objective, colonial powers began to explore the region, leading to discoveries of hides and ground nuts in the north and coal in the east (Oduwaye 2015). This was followed by the establishment of new settlements throughout the country, to serve as administrative headquarters and colonial outposts (Ikwuyatum 2016). While private enterprise and industrial production led to the growth of cities in the south, those in the east and west tended to rely more on government investment (Smythe 1960). To facilitate the extraction of goods, the British constructed a complex network of roads and railways, connecting these outposts to the important port cities of Lagos and Port Harcourt for the purpose of processing and exporting raw materials (Mabogunje 1968; Okwuashi et al. 2008). Settlements - new and old - that were favorably located along these transportation corridors, emerged as vital industrial, administrative, and port cities (O'Connor 1983); many of which have become pivotal cities in the twenty-first century-Enugu, Jos, Kaduna, Lagos, and Port Harcourt are notable examples.

It was not until the post-colonial period, however, that Nigeria's urban transition really began to take off. Much of this dramatic surge in urban population can be attributed to frequent political restructuring and an oil boom, both of which resulted in the widespread establishment of new urban centers and infrastructure investment throughout the country (Oduwaye 2015). With the arrival of new sectors, including banking, construction and tourism during the 1970s and 1980s, and the onset of globalization during the 1990s, urbanization continued to accelerate (Aliyu and Amdu 2017). According to Ikwuyatum (2016), it was the Yoruba people, with a preference for living in close proximity, that were the first to embrace urbanization. This helps to explain the higher concentration of urban settlements in the south-western region of the country; an area primarily inhabited by the Yoruba.

Figure 1 illustrates the evolution of Nigeria's urban system from the colonial period (represented by red points) to the post-colonial period (represented by blue points), reflecting a significant increase in the number of officially designated cities. What is interesting to note is that although the national urban system has become more widespread over time, economic development has not necessarily followed. The States 
that have demonstrated the highest levels of GDP per capita in 2010, more closely resemble the pre-colonial and colonial urban structures as opposed to the post-colonial one. This raises questions as to the relationship between urbanization and economic development in Nigeria; a topic explored in detail in Fox et al. (2017).

\section{Nigeria's Urbanization Curve}

Despite a tumultuous economy, Nigeria's urbanization has continued to forge ahead, with the most substantial increases in urban population projected to come. Nigeria's urbanization curve, depicted in Fig. 2, is characterized by three distinct stages: an initial stage reflecting a relatively gradual increase in urban population prior to the $1980 \mathrm{~s}$, followed by an accelerated stage reflecting a comparatively rapid increase between 1980 and 2030, and a terminal stage, again reflecting a rather gradual increase around 2030. The stages of the urban transition have been delineated in accordance with the corresponding speeds and levels of urbanization in Table 1 and 2 below. Over the course of this period, Nigeria will have gone from a country in which $15.4 \%$ of its

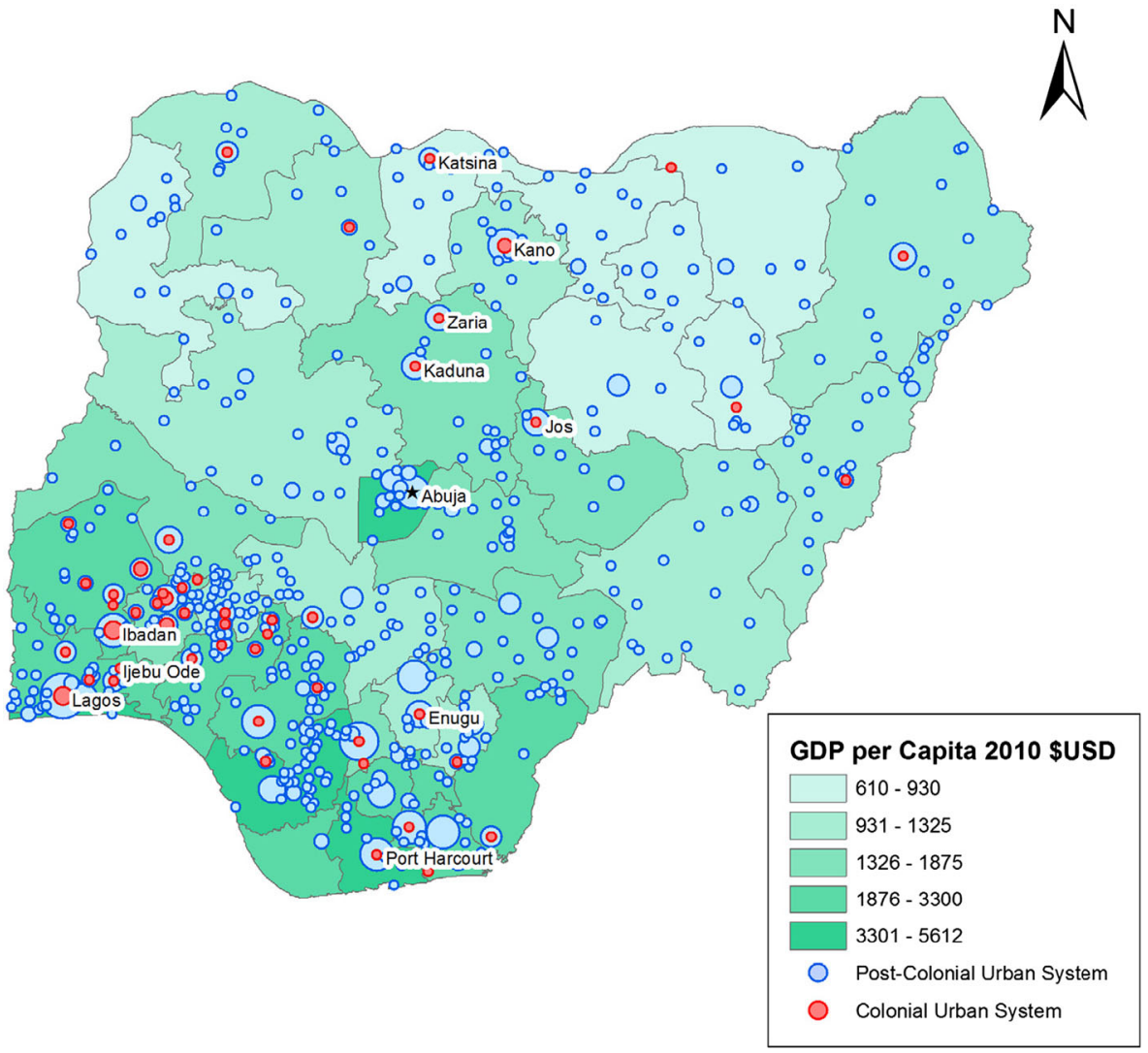

Fig. 1 Colonial and post-colonial urban systems and 2010 GDP per capita by State. Notes: Red points reflect the colonial urban system (1950), and blue points reflect the post-colonial urban system (2010). Source: Settlement data is from OECD (2017), accessed on 4 April 2017. GDP data is from Bloch et al. (2015b); GDP data was originally published by Nigeria's National Bureau of Statistics. Georeferenced and plotted by author 


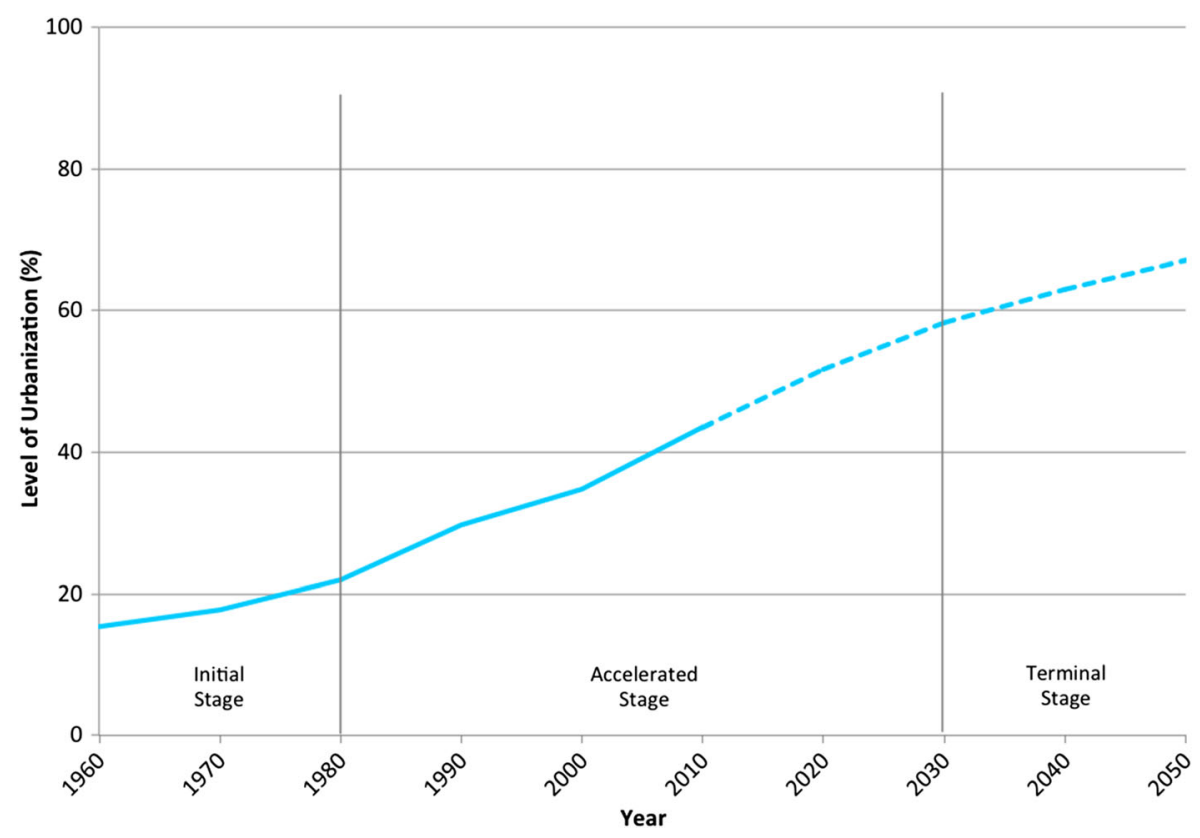

Fig. 2 Nigeria's urbanization curve, 1960-2050. Notes: In accordance with the speed and level of urbanization in Table 1 and 2 below, Fig. 2 illustrates the three stages of the urban transition - initial stage, accelerated stage, and the terminal stage. Source: Data is from the United Nations (2014)

population inhabited urban areas in 1960 , to one in which $67.1 \%$ are expected to inhabit urban areas by 2050. This structural transformation of society, in which more than 288 million inhabitants become urban, denotes one of the most dramatic urban transformations the world has seen; certainly, the most substantial in Africa.

\section{Pace and Scale of Nigeria's Urban Transition}

Perhaps the most dramatic feature of Nigeria's urban transition is the increase in the absolute number of urban dwellers and the speed at which it has unfolded. The speed or tempo of the urban transition can be measured in a number of ways: the annual rate at which the urban population is growing, the annual amount by which the level of urbanization is rising, the annual rate by which the level of urbanization is rising, and urban-rural growth differentials (United Nations 1974). The former provides a measure of urban growth, which refers to the rate of increase in the absolute number of urban dwellers, whereas the latter measures calculate urbanization, which is the difference between rural growth rates and urban growth rates (Davis 1965; Brockerhoff 2000). Tables 1 and 2 provide an overview of the urban and rural population trends and the speed of urban growth and urbanization between 1960 and 2050 .

What is immediately noticeable about Nigeria's urban transition in the post-colonial period is the significant population growth experienced in both urban and rural areas. Between 1960 and 2010, urban areas added approximately 62.5 million inhabitants to their population, while rural areas experienced an increase of approximately 52 million. 
Table 1 Urban and rural population trends, 1960-2050

\begin{tabular}{lllll}
\hline Year & $\begin{array}{l}\text { Total population } \\
\text { (thousands) }\end{array}$ & $\begin{array}{l}\text { Rural population } \\
\text { (thousands) }\end{array}$ & $\begin{array}{l}\text { Urban population } \\
\text { (thousands) }\end{array}$ & $\begin{array}{l}\text { Urbanization level } \\
(\%)\end{array}$ \\
\hline 1960 & 45,212 & 38,245 & 6,967 & 15.4 \\
1970 & 56,132 & 46,163 & 9,969 & 17.8 \\
1980 & 73,698 & 57,507 & 16,191 & 22.0 \\
1990 & 95,617 & 67,238 & 28,379 & 29.7 \\
2000 & 122,877 & 80,066 & 42,810 & 34.8 \\
2010 & 159,708 & 90,267 & 69,441 & 43.5 \\
2020 & 210,159 & 101,448 & 108,711 & 51.7 \\
2030 & 273,120 & 113,880 & 159,241 & 58.3 \\
2040 & 350,720 & 129,896 & 220,824 & 63.0 \\
2050 & 440,355 & 144,875 & 295,480 & 67.1 \\
\hline
\end{tabular}

Source: United Nations (2014)

Despite the annual rate of urban growth being higher than that of rural growth during the initial stage of the urban transition (1960-1980), rural growth rates were comparatively higher than in subsequent periods, which appears to have had an abating effect on the rate of urbanization (as can be seen by the urban-rural annual growth differentials). However, by the $1980 \mathrm{~s}$, this began to change. Dramatic increases in urban growth rates coincided with simultaneous decreases in rural growth rates, accelerating the overall urbanization process. The annual rate of urban growth reached a record high of $5.9 \%$ during the $1980 \mathrm{~s}$, with an urban-rural annual growth differential of $4.3 \%$, signifying the pinnacle of Nigeria's rapid ascent. The subsequent decades were characterized by a rather steady decline in the rate of rural population growth, with rates of urban population growth remaining high. Nigeria has since experienced a period of

Table 2 Urban and rural population growth rates and speed of urbanization, 1960-2050

\begin{tabular}{|c|c|c|c|}
\hline \multirow[t]{2}{*}{ Decade } & \multirow{2}{*}{$\begin{array}{l}\text { Annual rate of growth of rural } \\
\text { population }(\%)\end{array}$} & \multicolumn{2}{|c|}{ Speed of urban growth and urbanization } \\
\hline & & $\begin{array}{l}\text { Annual rate of growth of urban } \\
\text { population }(\%)\end{array}$ & $\begin{array}{l}\text { Urban-rural annual growth } \\
\text { differentials }(\%)\end{array}$ \\
\hline 1960-1970 & 1.9 & 3.7 & 1.8 \\
\hline 1970-1980 & 2.2 & 5.0 & 2.8 \\
\hline 1980-1990 & 1.6 & 5.9 & 4.3 \\
\hline $1990-2000$ & 1.8 & 4.2 & 2.4 \\
\hline 2000-2010 & 1.3 & 5.0 & 3.7 \\
\hline 2010-2020 & 1.2 & 4.7 & 3.5 \\
\hline $2020-2030$ & 1.2 & 3.9 & 2.7 \\
\hline 2030-2040 & 1.3 & 3.3 & 2.0 \\
\hline 2040-2050 & 1.1 & 3.0 & 1.9 \\
\hline
\end{tabular}

Source: United Nations (2014). Author's own calculations 
accelerated urbanization and urban growth that has lasted more than three decades. If the United Nations projections are accurate, Nigeria will continue to experience relatively accelerated speeds of urbanization and urban growth for another two decades, before eventually slowing. By 2030 it is expected that the urban transition will return to similar levels as experienced before takeoff, marking the beginning of the terminal stage of Nigeria's urban transition with approximately $60 \%$ of its population inhabiting urban areas.

\section{The Components of Urban Growth}

The aforementioned overview illustrates the origins of urban settlements and the overarching trends behind the urban transition in Nigeria. It falls short, however, of capturing the detailed complexity underpinning Nigeria's rapid urban transformation. These rather vague accounts are frequent among the urban studies discourse, with few studies attempting to examine the determinants behind the urban transition. Instead most take for granted that the urbanization process is already underway (Preston 1979; Dyson 2011).

The few studies that do attempt to examine the drivers have often done so in isolation. Economists have a tendency to explain the growth of cities through rural to urban migration as a response to changing labor markets; demographers turn to natural population increase as a result of changes in mortality and fertility rates; and those from the political studies discourse tend to view reclassification of rural areas as urban as an artifact of governance reform (Farrell 2017). There is thus a need for a more nuanced understanding of the urban transition (Beall et al. 2010). There are, however, some recent studies that have made a concerted effort to offer a more detailed explanation of the urban transition at the country level; Brazil (see Martine and McGranahan 2010), Ghana (see Songsore 2009), and the Philippines (see Porio 2009) to name a few. In an attempt to refute the stalled urbanization hypothesis in Nigeria (see Potts 2012a), a recent paper by Fox et al. (2017) provided a more holistic account of Nigeria's urban transition; underscoring the significance of demographic factors in explaining the growth of Nigeria's cities. This has helped make sense of Nigeria's persistent urbanization despite continuous economic stagnation. Building on this, the remainder of this section empirically examines the components of urban growth and computes their individual contributions to Nigeria's urban transformation between 1960 and 2010.

\section{Natural Population Increase in Urban Areas}

Natural population increase is best understood through the demographic transition model proposed by Thompson (1929). This model is used to depict changes in birth and death rates as a country develops over time. In the first stage of the demographic transition, birth rates and death rates are high and population growth is stagnated; in the second stage of the transition, there is a decline in death rates while birth rates remain high resulting in rapid population growth; and in the final stage of the transition, birth rates adjust to the decline in death rates and population growth becomes limited (Todaro and Smith 2012). Nigeria, as the most populous country in Africa, is considered to be in the accelerated stage of its demographic transition. Table 3 displays 
Table 3 Births, deaths, and natural increase per 1000 persons, 1960-2010

\begin{tabular}{llll}
\hline Year & Birth rate (per 1000) & Death rate (per 1000) & Rate of natural increase (per 1000) \\
\hline 1960 & 46.34 & 26.38 & 19.96 \\
1970 & 46.32 & 22.81 & 23.51 \\
1980 & 46.95 & 19.41 & 27.54 \\
1990 & 44.26 & 18.58 & 25.68 \\
2000 & 43.15 & 17.89 & 25.26 \\
2010 & 41.34 & 14.31 & 27.03 \\
\hline
\end{tabular}

Source: World Bank (2017), accessed 1 October 2017

Nigeria's demographic transition between 1960 and 2010, highlighting the changes in birth and death rates and the overall rate of natural increase per 1000 persons.

In accordance with the demographic transition, as of 1960, Nigeria was experiencing high birth rates accompanied by high death rates, resulting in a rate of natural increase of approximately 20 per 1000 persons. Since then, the widespread provision of basic services and improved access to public health services have led to death rates being nearly halved; however, birth rates still remain high. This has resulted in a rate of natural increase of approximately 27 per 1000 persons; a 35\% increase. Although this high rate of natural increase represents a deviation from historical accounts of the demographic transition, such a large window of high birth rates and low death rates is not particularly uncommon among countries in sub-Saharan Africa (Kessides 2007; Agunwamba et al. 2009).

Declines in fertility rates can be brought about through a number of economic, social, and biological factors: cost of living, education, age at marriage, access to contraceptives, type of religion, family pressure, child mortality, reproductive life span, and so on (Ghatak 1995; Todaro and Smith 2012). In the case of Nigeria, previous studies have attributed its high fertility rates to a desire for children, tendency towards polygamous relationships, a preference for children of a particular sex, ignorance to the implications of larger families, and reluctance towards family planning (Akpotu 2008; Feyisetan and Bankole 2002; Agunwamba et al. 2009). With many of these factors closely related to ethnicity and religion, fertility patterns in Nigeria tend to vary by region. In the north, which is home to the 12 (out of 36) states governed under Sharia Law, polygamous relationships remain pervasive. As of 2014, the northern states of Bauchi and Katsina both had average fertility rates above 8 births per woman, notably higher than the country average of 5.5 births per woman (National Bureau of Statistics 2014a).

The sector specific model of the demographic transition depicts urban-rural differentials in mortality and fertility rates. It illustrates that as death rates fall below birth rates in urban areas, urban growth will occur as a result of natural population increase (de Vries 1990). Better access to basic services and health facilities secures that mortality rates are almost always lower in urban areas. Evidence of this can be seen in Nigeria's Demographic Health Survey, which shows that under-5 mortality in urban areas was 100 per 1000 live births, whereas in rural areas, it was 167 (National Population Commission 2013). Additionally, Chen and Zlotnik (1994) point to 
evidence of a selection bias pertaining to rural to urban migration, noting that rural migrants tend to be younger and more likely to be of child-bearing age; this is particularly the case in African countries where there are limited employment and education opportunities in rural areas. Despite urban areas usually being associated with a steady fertility decline, in the case of Nigeria, urban fertility has remained comparatively high; 4.7 children per woman in urban areas compared with 6.2 in rural areas (National Population Commission 2013). Urban natural increase in the context of Nigeria thus needs to be understood against the backdrop of comparatively higher life expectancy in urban areas coupled with slow fertility decline.

\section{Rural to Urban Migration}

Rural to urban migration has traditionally been understood through the Lewis Dual Sector Model (Lewis 1954) and the Harris-Todaro Model (Harris and Todaro 1970). Both models assert that the decision to migrate is a response to employment opportunities, reflected by rural-urban income gaps. These models distinguish themselves in that the Lewis Dual Sector Model argues that migration will persist until a wage equilibrium between rural and urban areas stabilizes; whereas, the Harris-Todaro Model posits that institutionally determined wages are the attractor of rural migrants, and migration will continue even when high levels of urban unemployment persists.

When it comes to rural to urban migration in Africa, urban pull factors such as higher wages in urban areas, reveal only half the story. This was made clear in a landmark article by Fay and Opal (2000), which draws attention to the concept of urbanization without growth. Unlike historical accounts that demonstrated a positive linear relationship between urbanization and economic growth, the experiences of African countries have been much more varied. This triggered a noticeable shift in dialog, from early explanations of migration premised on urban pull factors, to a more open discussion acknowledging rural push factors. An overview of the rural push literature demonstrates that rural to urban migration could be warranted under a variety of other circumstances: Malthusian theory consisting of pressure on natural resources, natural or man-made disasters, rural poverty, surplus labor due to the "green revolution," and wars and conflict (Preston 1979; Bairoch 1988; Oberai 1993; Gollin et al. 2002; Fay and Opal 2000).

In the case of Nigeria, rural to urban migration has been on the rise since independence. A recent governmental survey noted employment as the top explanatory factor behind migration in Nigeria (National Population Commission 2010). Figure 3 illustrates the structural transformation of Nigeria's society in the form of changing employment markets between 1970 and 2010. During this time, the share of agricultural employment fell drastically by $19 \%$, with the service industry experiencing a substantial growth of $21 \%$. Growing employment opportunities in the service industry, which is predominantly found in urban areas, serves as a strong pull factor attracting migrants in search of higher wages (Ogun 2010). During this time, the share of employment opportunities in heavy industry experienced a modest boost of $4 \%$, with a subsequent decline of $5 \%$ in the manufacturing sector.

Another explanation for Nigeria's accelerating rural to urban migration is rural push factors, resulting from growing unemployment in certain regions of the country. The unemployment line in Fig. 3 illustrates that unemployment has risen drastically from 


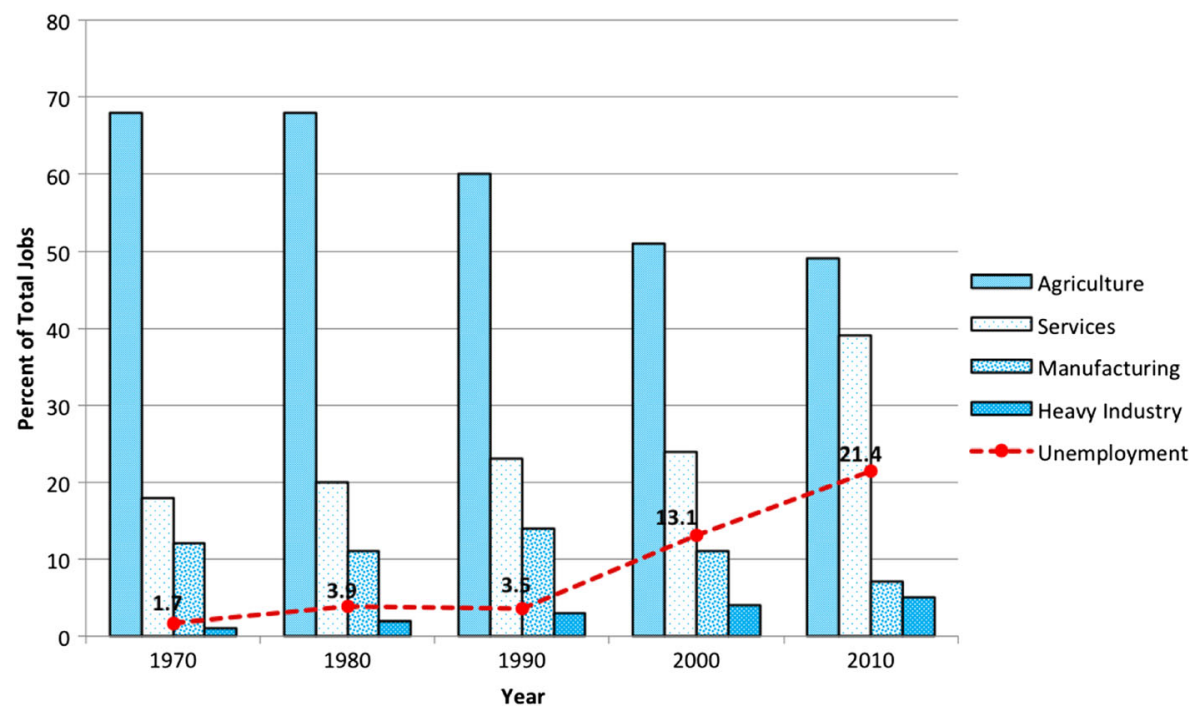

Fig. 3 Trends in employment by sector and total unemployment, 1970-2010. Note: Heavy industry refers to mining and quarrying, construction, electricity, gas, and water. Unemployment data for 1970 and 1980 were taken from closest available years (1967 and 1983). Source: Employment data is from Ajakaiye et al. (2015); originally compiled by NISER (2015). Unemployment data is from National Bureau of Statistics (2014b)

$1.7 \%$ in 1970 to over $21.4 \%$ by 2010 . According to the World Bank (2016), the effects of Nigeria's unemployment have been felt the hardest in the northern parts of the country where the majority of the population is engaged in agricultural activities. Increasing insecurity in the northeast, due to the emergence of Boko Haram, has also been linked to the intensification of rural to urban migration in recent years (The Economist 2015).

It should be noted that migration is a multidimensional and dynamic process. It can take the form of either internal or international migration streams. In terms of internal migration, this can occur as rural to rural, rural to urban, urban to rural and urban to urban (Oyeniyi 2013). It also occurs in the form of one-way, temporary, circular, and stepwise migration patterns. Temporary migration has long been a critical element of income distribution for rural households, with migrants usually moving to urban areas on a seasonal basis, while maintaining permanent ties to rural areas (Awumbila 2017). Potts (2012b) recently noted that circular migration has been on the rise in many African countries, with the average duration of stay decreasing over time. Should this be the case, then it is likely that much of it is occurring between census counts, and outside of the purview of official statistics. Stepwise migration usually involves migrants first moving to nearby villages and towns before moving on to larger cities, but it can also serve as a springboard to international migration (Bakewell and Jonsson 2011). When it comes to international migration, however, Nigeria's rate of net-migration is rather low compared with other countries in the region, registering $-0.35 / 1000$ persons as of the latest survey (United Nations 2013). The dearth of reliable data on migration in Nigeria makes it difficult to piece together a comprehensive narrative. 


\section{Reclassification of Rural Areas as Urban}

Reclassification of rural areas as urban, which is generally considered an administrative form of urbanization, is most often used to promote more balanced economic development and to bring infrastructure and amenities to neglected regions (Kulcsar and Brown 2011). Reclassification can occur in a number of ways: the expansion of existing city boundaries to include neighboring settlements, the annexation of adjacent settlements, the creation of entirely new cities, rural areas that grow beyond a size threshold and are reclassified as urban, and the occasional changing of the definition as to what constitutes urban and rural areas (United Nations 2001; Montgomery et al. 2004). Reclassification is considered a significant accelerator of urban growth, because when newly classified settlements are added to the urban population, they experience an immediate bump in the overall urban population count. Despite the significance of this component of urban growth, the process of reclassification is generally overlooked within the literature. ${ }^{6}$

Figure 4 provides an overview of the increase in the number of urban settlements in Nigeria between 1960 and 2010. Nigeria went from a system of 109 urban settlements in 1960 , to 536 in 2010 . The most substantial increase was experienced in the last two decades, with 112 new urban settlements added between 1990 and 2000, and 144 added between 2000 and 2010.

Prior to independence, Nigeria was composed of four major regions (Northern Region, Western Region, Eastern Region, and mid-Western Region). However, resulting from a military decree in 1967 under the administrative authority of General Yakubu Gowon, these regions were dissolved and replaced by 12 states. It was thought that decentralization would promote more balanced development and enable the spread of further amenities and opportunities (Adetoye 2016). This process of political restructuring became a common theme in the post-colonial period, leading to the addition of seven new states in 1976, two new states in 1987, nine more states and one Federal Capital Territory (Abuja FCT) in 1991, and six more states in 1996, bringing the total as it stands today to 36 states and 1 Federal Capital Territory (Moriconi-Ebrard et al. 2016). This political restructuring was recognized as a major accelerator of urbanization, as each of the new states was equipped with state capitals accompanied by a massive influx of infrastructure investment. According to Ayeni (1982), the growth of state capitals was further compounded by a substantial increase in the number of rural-urban migrants in search of employment opportunities.

The most prominent example of reclassification due to political restructuring was that of Abuja. Following a similar rationale as Brasilia, Abuja was constructed from scratch as a purpose-built city; serving as the political capital of the country. Between 2000 and 2010, it grew at a rate of nearly $140 \%$ and was considered the world's fastest growing city; and as of the most recent census, it had a population of 1.8 million inhabitants (United Nations 2014). Other instances of reclassification include spatial expansion and annexation of neighboring settlements. Lagos, for example, nearly tripled in size between 1984 and 2010 (Angel 2018). In the process, it grew into

\footnotetext{
${ }^{6}$ This is likely due to the fact that reclassification is not an explicitly obvious contributor to urban growth, and because of the difficulty measuring its contribution. Statistics on reclassification are rarely recorded among countries.
} 


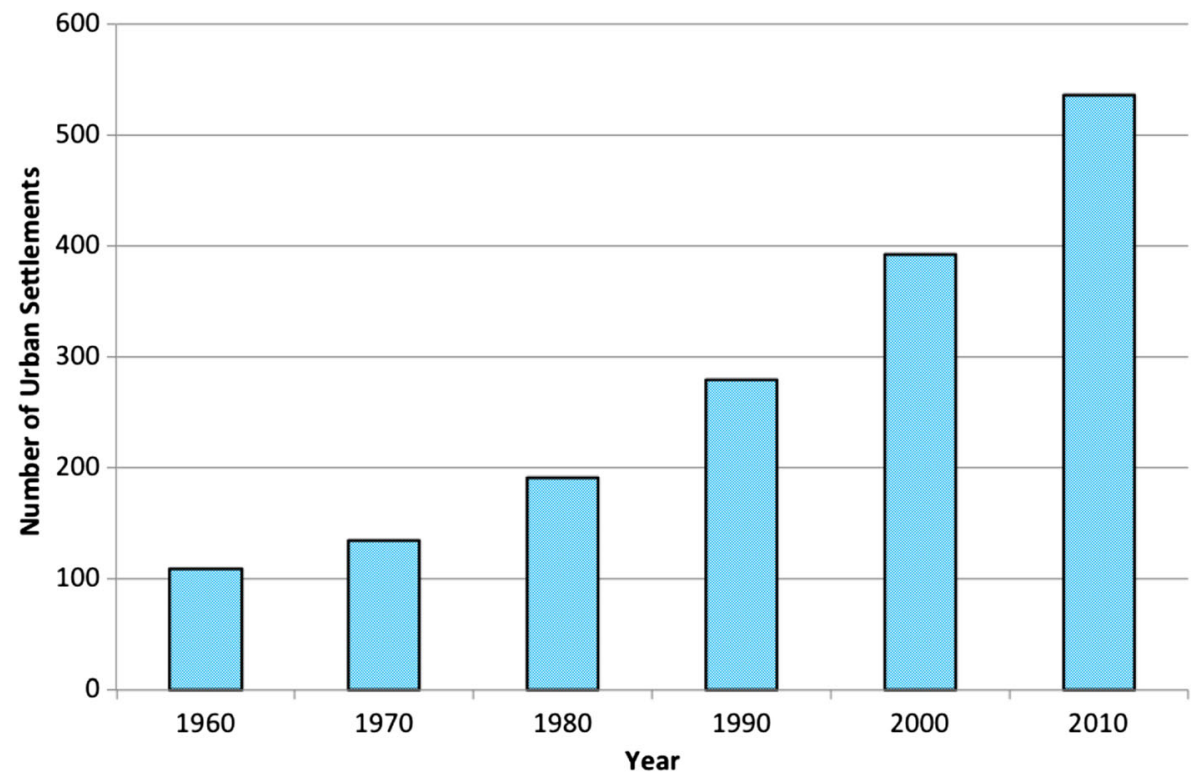

Fig. 4 Total number of urban settlements in Nigeria over 20,000 inhabitants, 1960-2010. Source: Data is from OECD (2017), accessed on 4 April 2017

neighboring Ogun State, absorbing adjacent settlements such as Ifo and Obafemi Owode along the way (Wang and Maduako 2018). Another less recognized form of reclassification in Nigeria has been the growth of rural settlements beyond the population threshold of 20,000 inhabitants, qualifying them as urban settlements. Given that Nigeria has undergone significant population growth in recent years, this has become the most prevalent source of reclassification.

\section{Disaggregating Urbanization into Its Individual Components of Urban Growth}

Building on the above analysis, the individual contributions of the components of urban growth to the overall urban increment for each decade between 1960 and 2010 have been computed. Given that the preferred data to perform a rigorous analysis does not exist in Nigeria, this paper has opted to apply the "National Growth Rate Method (Siegel and Swanson 2004). Using the average annual growth rates of the total population for each decade, the National Growth Rate Method calculates estimates of the urban population increase between two census counts. The estimated urban population represents the portion of the population that is attributable to urban natural population increase during that period. This is then deducted from the actual urban population count from the following decade, leaving a residual, which represents a combination of rural to urban migration and reclassification. As a variation to the original methodology, the populations of all newly classified cities between the two decades is added together and deducted from the residual, resulting in a disaggregated account of the newly classified cities and an estimate of the number of rural to urban migrants during that decade. This generates the individual contributions for each component of urban growth during each decade. 
This method is considered to be a crude but common approach in circumstances of limited data (Shryock et al. 1971; Rahman 2013). It is premised on two assumptions: firstly, that there is zero net international migration within the country; and, secondly, that the national growth rate, which is used in the calculation, is uniform throughout the country (Rahman 1987). In the case of net-immigration from other countries, this variable tends to be significantly smaller than that of internal migration, unlikely causing drastic distortions in the estimates (Chen and Valente 1998). Nevertheless, given that the growth rate between rural areas and urban areas is likely different, the findings of this analysis should still be treated as a crude estimate. In light of these limitations, this approach is still useful in providing a general indication of the trends pertaining to the contribution of each of the components of urban growth in Nigeria.

Table 4 provides a disaggregated account of Nigeria's urbanization with decadal estimates for each component between 1960 and 2010. This indicates that urban natural population increase, accounting for on average $50 \%$ of the urban increment between 1960 and 2010, is the dominant component underpinning Nigeria's urban transformation in the post-colonial period. As noted above, this has to do with the significant declines in mortality rates coupled with persistently high fertility rates, an argument also put forth by Fox et al. (2017). The next most significant contributor is rural to urban migration, accounting for on average 32\% of the urban increment between 1960 and 2010. This increase in migration could quite possibly be a result of the limited state restructuring during these periods, meaning rural to urban migration was necessary for those to access expanding labor markets. Finally, this is followed by reclassification with a contribution averaging $18 \%$ between 1960 and $2010 .^{7}$ The trend observed for reclassification roughly, shadows that of the state restructuring policies during this period making this a likely explanatory factor; but it is also greatly influenced by urban expansion and settlements crossing the population threshold of 20,000 inhabitants.

\section{Discussion}

In accordance with the speed and level of urbanization noted above, this paper has identified and delineated among the different stages of Nigeria's urban transition. The results are summarized in Table 5 below. During the initial stage (1960-1980), urbanization unfolded at a fairly moderate pace $(2.3 \%)$, resulting in a gradual increase in the proportion of the population living in urban areas from 15.4 to $22 \%$. Following this, Nigeria entered the accelerated stage (1980-2030), and as the name suggests, the pace of urbanization began to takeoff; achieving a particularly rapid urbanization rate of $3.3 \%$. After which, Nigeria is expected to enter the terminal stage of its urban transition (2030-2050), again characterized by moderate rates of urbanization (2.0\%). In fact, by the time Nigeria enters the terminal stage, all measures of growth will have dropped below the levels they were at during the initial stage of the urban transition. The period of rapid urban growth and rapid urbanization will thus be a thing of the past. These forecasts seem to indicate that Nigeria, which is often described as a late urbanizer, has

\footnotetext{
${ }^{7}$ Although reclassification has demonstrated an upward trend in Fig. 4, having added 427 urban settlements between 1960 and 2010, its declining contribution to the overall urban increment in Table 4 is likely a result of the increase in the absolute number of inhabitants contributed to by the other components.
} 


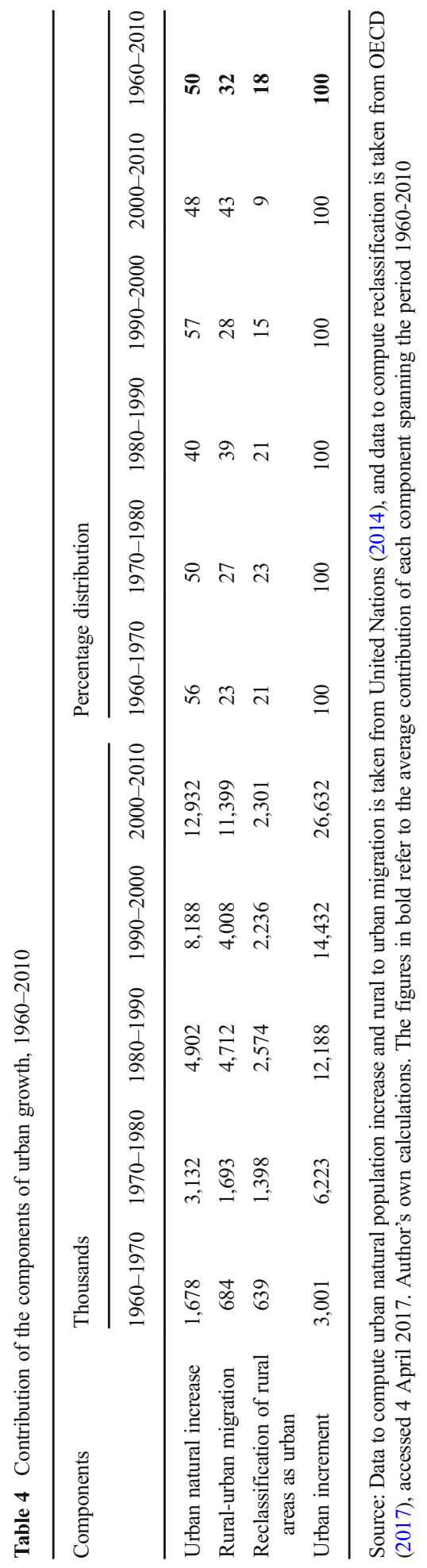


already crossed the point at which it was expected to experience its most accelerated rates of urbanization and has now entered the deceleration phase.

Furthermore, this paper has empirically demonstrated that urban natural population increase has been the dominant component of urban growth in the post-colonial period and will likely continue to be so in the immediate future. During the initial stage of the urban transition, urban natural increase accounted for $53 \%$ of the urban increment; this was followed by rural to urban migration $(25 \%)$ and then reclassification $(22 \%)$. This trend continued as Nigeria entered the early-accelerated stage of the urban transition, with urban natural increase continuing to represent the dominant share (48\%), followed by rural to urban migration $(37 \%)$ and then reclassification $(15 \%)$ as the next most significant contributor. These findings build on a previous study by Fox et al. (2017), which also arrived at the conclusion that urban natural increase was the dominant driver underpinning Nigeria's urban transition. This study, however, differentiates itself in that it disaggregates urbanization into its individual components of urban growth and computes their individual contributions to the overall urban increment.

The relevance of this study can be found in its application to policy. A survey conducted by the United Nations (2013) spanning the years 1986-2013 notes that the Nigerian government has been seriously concerned with the growth rate of the population and the rate of rural to urban migration; underscoring that policies should be

Table 5 Speed and drivers for each stage of Nigeria's urban transition

\begin{tabular}{llll}
\hline $\begin{array}{l}\text { Initial stage } \\
(1960-1980)\end{array}$ & Accelerated stage $(1980-2030)$ & $\begin{array}{l}\text { Terminal stage } \\
(2030-2050)\end{array}$ \\
\cline { 2 - 3 } & $\begin{array}{ll}\text { Early-accelerated } \\
(1980-2010)\end{array}$ & $\begin{array}{l}\text { Late-accelerated } \\
(2010-2030)\end{array}$ \\
\hline
\end{tabular}

Speed/tempo of the urbanization curve

Level of urbanization

$15.4-22 \%(\Delta 6.6 \%) \quad 22-43.5 \%(\Delta 21.5 \%) \quad 43.5-58.3 \%(\Delta 14.8 \%) \quad 58.3-67.1 \%(\Delta 8.8 \%)$

Average urbanization rate

\begin{tabular}{|c|c|c|c|}
\hline $2.3 \%$ (moderate) & $3.5 \%$ (rapid) & $3.1 \%$ (rapid) & $2.0 \%$ (moderate) \\
\hline \multicolumn{4}{|c|}{ Average rural growth rate } \\
\hline $2.1 \%$ (moderate) & $1.6 \%$ (slow) & $1.2 \%$ (slow) & $1.2 \%$ (slow) \\
\hline \multicolumn{4}{|c|}{ Average urban growth rate } \\
\hline $4.4 \%$ (rapid) & $5.0 \%$ (rapid) & $4.3 \%$ (rapid) & $3.2 \%$ (rapid) \\
\hline \multicolumn{4}{|c|}{ Components of urban growth } \\
\hline \multicolumn{4}{|c|}{ Urban natural increase } \\
\hline $53 \%$ & $48 \%$ & $\mathrm{n} / \mathrm{a}$ & $\mathrm{n} / \mathrm{a}$ \\
\hline \multicolumn{4}{|c|}{ Rural to urban migration } \\
\hline $25 \%$ & $37 \%$ & $\mathrm{n} / \mathrm{a}$ & $\mathrm{n} / \mathrm{a}$ \\
\hline \multicolumn{4}{|l|}{ Reclassification } \\
\hline $22 \%$ & $15 \%$ & $\mathrm{n} / \mathrm{a}$ & $\mathrm{n} / \mathrm{a}$ \\
\hline
\end{tabular}

Note: Since figures beyond 2010 are based on projections, the accelerated stage has been divided into an earlyaccelerated period and a late-accelerated period. Speed classifications are as follows: negative $(<0 \%)$, stagnant $(0-1 \%)$, slow (1-2\%), moderate $(2-3 \%)$, and rapid $(>3 \%)$ 
implemented to lower both. Evidence however, seems to suggest a historical preference on behalf of the government to actively deter rural to urban migration in order to manage the urban transition - accounts of forced eviction (The Guardian 2017); barriers to employment for rural migrants in urban areas (Ajakaiye et al. 2015) and a history of policies directed at rural areas to prevent rural to urban migration (Abbass 2012; Federal Republic of Nigeria 2012). ${ }^{8}$ This position is not uncommon among African countries, many of which still promote "urban-bias" legacies (Turok and Parnell 2009). Whereas, efforts to reduce natural population increase have tended to be more passive in nature. Agunwamba et al. (2009) notes that aside from a failed effort to reduce fertility in 1988 , the government has primarily relied on international organizations and civil society to promote initiatives such as sexual education and distribution of contraceptives. ${ }^{9}$ Despite this paper identifying urban natural population increase as the dominant component of urban growth, the evidence seems to point towards a potential policy mismatch. Should the government be interested in alleviating the population pressures on its cities, programs aimed at reducing fertility rates could potentially go much further.

\section{Conclusion}

When managed, urbanization has the ability to contribute to the social and economic development of a country. However, with the unprecedented pace and scale of the urban transition in many developing countries currently outstripping the capacity of local governments to provide the necessary housing, infrastructure, and amenities to cope with a growing urban population, such outcomes are not guaranteed. It is thus important that policymakers gain greater insights into the dynamics underpinning the urban transition. Only then will they be able to establish effective policies and provide more targeted interventions for managing the urban transition in a more strategic manner.

This paper has examined Nigeria's urban transition between 1960 and 2010, taking stock of past experiences, identifying trends and speculating on future growth trajectories. In doing so, it has found that Nigeria is in the accelerated stage of its urban transition, with urban natural increase as the dominant component of urban growth. Despite this being the case, the Nigerian government appears to favor policies directed towards restricting rural to urban migration in order to alleviate the pressures posed by its rapid urban transition. Not only is this policy mismatch unlikely to achieve its intended goal of alleviating the pressures of rapid urban growth but it is also likely to work against the forces of economic development, while causing unnecessary harm to those who rely on migration as a livelihood strategy (Chen and Zlotnik 1994; Turok and McGranahan 2013).

Beyond Nigeria, the findings of this paper have wider theoretical and policy relevance. From a theoretical perspective, this paper has advocated for the need

\footnotetext{
${ }^{8}$ The National Urban Development Policy and Urban and Regional Planning Act of 1992.

${ }^{9}$ In 1988, Nigeria introduced measures to reduce fertility levels to four children. The policy was heavily criticized for placing the onus on women, without addressing patriarchal family structures (Agunwamba et al. 2009).
} 
to go beyond a uniform understanding of the urban transition to a more nuanced one, accounting for the different stages of the urban transition and the varying combinations of the components of urban growth. A notion that has implications for how we interpret and respond to the challenges and opportunities presented by rapid urban growth and rapid urbanization. Furthermore, it has highlighted a need to evaluate existing policies against the backdrop of the contemporary urban narrative. Several studies in recent years have noted that urban natural population increase is taking on a growing share of the overall urban increment in developing countries, accounting for approximately $60 \%$, while rural to urban migration and reclassification account for the remaining 40\% (Chen and Valente 1998; Farrell 2017); albeit, this varies significantly by country. ${ }^{10}$ Meanwhile, the United Nations (2013) have reported that 118 countries in less developed regions have policies oriented towards reducing rural to urban migration. Not only does this speak to the concern of persisting legacies of urban bias but it also speaks to the vast number of misguided policy interventions, a lacuna this paper has attempted to address. Stemming from all this, this paper urges those working at the crossroads of urban and economic development to rethink conventional theories and policies to better reflect country-specific circumstances and the changing conditions of the contemporary urban narrative.

To the author's knowledge, this is the first paper to disaggregate urbanization into its individual components of urban growth for Nigeria. Nonetheless, it suffers from several limitations. Most notably, since separate data on the growth rate of urban and rural populations is not available for the time period spanning 1960-2010, this study has relied on the combined national growth rate when disaggregating urbanization into the individual components of urban growth; likely inflating the true effects of natural population increase in urban areas. Although this paper has primarily focused on Nigeria's urban transition, it does raise a number of thought-provoking questions that would be of interest to a wider audience. Does a higher contribution of urban natural increase (as opposed to rural to urban migration or reclassification) explain persistent urbanization in the absence of per capita GDP growth, as was experienced in Nigeria at specific points in time? What is the relationship between the different components of urban growth and the socioeconomic development of a country? Is there a preferred growth trajectory among countries? It is hoped that future research will continue to push the boundaries, further shedding light on these unresolved questions.

Acknowledgments The author would like to thank the anonymous reviewers for their comments.

Funding Information Additionally, the author would like to thank the Axel and Margaret Ax:son Johnson Foundation for providing a grant to make this research possible.

\section{Compliance with Ethical Standard}

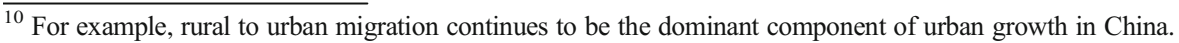


Conflict of Interest The author declares that he has no conflict of interest.

Open Access This article is distributed under the terms of the Creative Commons Attribution 4.0 International License (http://creativecommons.org/licenses/by/4.0/), which permits unrestricted use, distribution, and reproduction in any medium, provided you give appropriate credit to the original author(s) and the source, provide a link to the Creative Commons license, and indicate if changes were made.

\section{References}

Abbass, I. (2012). Trends of rural-urban migration in Nigeria. European Scientific Journal, 8(3), 97-125.

Adetoye, D. (2016). The political economy of state creation and socioeconomic development in Nigeria. European Journal of Research in Social Sciences, 4(2), 36-44.

Agunwamba, A., Bloom, D., Friedman, A., Ozolins, M., Rosenberg, L., Steven, D., \& Weston, M. (2009). Nigeria: The next generation - Literature review. In British Council and Harvard School of Public Health.

Ajakaiye, O., Jerome, A., Nabena, D., \& Alaba, O. (2015). Understanding the relationship between growth and employment in Nigeria. In WIDER working paper 2015/124. UNU-WIDER: Helsinki.

Akpotu, N. (2008). Education as correlate of fertility rate among families in southern Nigeria. Journal of Human Ecology, 23(1), 65-70.

Aliyu, A., \& Amdu, L. (2017). Urbanization, cities and health: the challenges to Nigeria - a review. Annals of African Medicine, 16(4), 149-158.

Angel, S. (2018). Atlas of urban expansion. Available at: http://www.atlasofurbanexpansion.org. Accessed 24 April 2018.

Annez, P., \& Buckley, R. (2009). Urbanization and growth: setting the context. In M. Spence, P. Annez, \& R. Buckley (Eds.), Urbanization and growth: commission on growth and development (pp. 1-46). Washington, DC: World Bank.

Awumbila, M. (2017). Drivers of migration and urbanization in Africa: key trends and issues. United Nations Expert Group Meeting on Sustainable Cities, Human Mobility and International Migration. Department of Economic and Social Affairs, Population Division. New York: United Nations.

Ayedun, C., Durodola, O., \& Akinjare, O. (2011). Towards ensuring sustainable urban growth and development in Nigeria: challenges and strategies. Business Management Dynamics, 1(2), 99-104.

Ayeni, B. (1982). Political Processes and Regional Development. United Nations Centre for Regional Development. Working Paper 82-7. Nagoya: UNCRD.

Bairoch, P. (1988). Cities and economic development: from the dawn of history to the present. Chicago: University of Chicago Press.

Bakewell, O., \& Jonsson, G. (2011). Migration, mobility and the African City: synthesis report on the African perspectives on human mobility research programme. Oxford: International Migration Institute.

Beall, J., Guha-Khasnobis, B., \& Kanbur, R. (2010). Introduction: African development in an urban world: beyond the tipping point. Urban Forum, 21, 187-204.

Bloch, R., Fox, S., Monroy, J., \& Ojo, A. (2015a). Urbanisation and urban expansion in Nigeria. Urbanization Research Nigeria (URN) research report. London: ICF International.

Bloch, R., Makarem, N., Yunusa, M., Papachristodoulou, N. \& Crighton, M. (2015b). Economic development in urban Nigeria. Urbanization Research Nigeria (URN) research report. London: ICF International.

Brockerhoff, M. (2000). An urbanizing world. Population Bulletin, 55(3), 1-44.

Bryman, A. (2012). Social research methods (4th ed.). New York: Oxford University Press.

Chen, N., Valente, P., \& Zlotnik, H. (1998). What do we know about recent trends in urbanization. In R. Bilsborrow (Ed.), Migration, urbanization and development: new directions and issues (pp. 59-88). New York: United Nations Fund for Population Activities.

Chen, N., \& Zlotnik, H. (1994). Urbanization prospects for the 21st century. In L. Mazur (Ed.), Beyond the number: a reader on population, consumption and the environment (pp. 343-358). Washington DC: Island Press.

Davis, K. (1965). The urbanization of the human population. Scientific American, 213(3), 40-53.

de Vries, J. (1990). Problems in the measurement, description, and analysis of historical urbanization. In A. Van der Woude, A. Hayami, \& J. de Vries (Eds.), Urbanization in history (pp. 43-60). Oxford: Clarendon Press.

Dyson, T. (2011). The role of the demographic transition in the process of urbanization. Population and Development Review, 37, 34-54. 
Farrell, K. (2017). The rapid urban growth triad: a new conceptual framework for examining the urban transition in developing countries. Sustainability, 9(8), 1-19.

Fay, M., \& Opal, C. (2000). Urbanization without growth: a not-so-uncommon phenomenon. Policy Research Working Paper No. 2412. Washington DC: The World Bank.

Federal Republic of Nigeria. (2012). National urban development policy 2012. Abuja: Federal Ministry of Lands, Housing and Urban Development.

Feyisetan, B., \& Bankole, A. (2002). Fertility transition in Nigeria: trends and prospect. In Population Bulletin of the United Nations: completing the fertility transition. New York: United Nations Department of Economic and Social Affairs.

Fox, S. (2011). Understanding the Origins and Pace of Africa's Urban Transition. In Working Paper Number 89. London: Crisis States Research Center.

Fox, S., Bloch, R., \& Monroy, J. (2017). Understanding the dynamics of Nigeria's urban transition: a refutation of the 'stalled urbanization' hypothesis. Urban Studies, 00(0), pp. 1-18.

Ghatak, S. (1995). Introduction to development economics (third ed.). London: Routledge.

Glaeser, E. (2013). A world of cities: the causes and consequences of urbanization in poorer countries. National Bureau of Economic Research, Working Paper 19745, pp. 1-60.

Glaeser, E., \& Xiong, W. (2017). Urban productivity in the developing world. Oxford Review of Economic Policy, 33(3), 373-404.

Gollin, D., Parente, S., \& Rogerson, R. (2002). The role of agriculture in development. American Economic Review, 92(2), 160-164.

Harris, J., \& Todaro, M. (1970). Migration, unemployment and development: a two-sector analysis. American Economic Review, 60(1), 126-142.

Ikwuyatum, G. (2016). Migration and urbanization: exploring the factors of the Nexus in Nigeria. International Journal of Humanities and Social Science, 6(8), 161-175.

Kasarda, J., \& Crenshaw, E. (1991). Third world urbanization: dimensions, theories and determinants. Annual Review of Sociology, 17, 467-501.

Kessides, C. (2007). The urban transition in sub-Saharan Africa: challenges and opportunities. Environment and Planning C: Politics and Space, 25, 466-485.

Kulcsar, L., \& Brown, D. (2011). The political economy of urban reclassification in post-socialist Hungary. Regional Studies, 45(4), 479-490.

Lewis, A. (1954). Economic development with unlimited supplies of labor. The Manchester School, 22, 139191.

Mabogunje, A. (1968). Urbanization in Nigeria. London: University of London Press.

Martine, G., \& McGranahan, G. (2010). Brazil's early urban transition: what can it teach urbanizing countries? London: International Institute for Environment and Development.

Montgomery, M., Stren, R., Cohen, B., \& Reed, H. (2004). Cities transformed: demographic change and its implications in the developing world by the panel on urban population dynamic (pp. 75-107). London: Earthscan.

Moriconi-Ebrard, F., Harre, D., \& Heinrigs, P. (2016). Urbanization dynamics in West Africa 1950-2010: Africapolis I, 2015 update, West African Studies. Paris: OECD Publishing.

Mulligan, G. (2013). Revisiting the urbanization curve. Cities, 32, 113-122.

National Bureau of Statistics (2014a). Statistical report on women and men in Nigeria: 2013. Federal Government of Nigeria.

National Bureau of Statistics. (2014b). Report of national stakeholders' workshop on the review of definition and methodology for computing unemployment statistics in Nigeria.

National Population Commission. (2010). International migration survey in Nigeria. Federal Republic of Nigeria.

National Population Commission. (2013). Nigeria demographic and health survey: key findings. Federal Republic of Nigeria.

NISER. (2015). Estimated employment (trend in gainful employment) from 1970-2014 by sectors. Ibadan: Nigerian Institute of Social and Economic Research.

Northam, R. (1975). Urban geography. Toronto: John Wiley and Sons, Inc.

O'Connor, A. (1983). The African city. London: Hutchinson.

Oberai, A. (1993). Urbanization, development, and economic efficiency. In J. Kasarda \& A. Parnell (Eds.), Third world cities: problems, policies, and prospects (pp. 58-73). London: Sage Publications.

Oduwaye, L. (2015). Urban land use planning and reconciliation. An inaugural lecture delivered at the University of Lagos. Lagos: University of Lagos Press.

OECD. (2017). Africapolis list and population of west African urban agglomerations, 1950-2010. Available at: http://stats.oecd.org/Index.aspx?QueryId=65660. Accessed 4 April 2017. 
Ogun, T. (2010). Infrastructure and poverty reduction: implications for urban development in Nigeria. Urban Forum, 21, 249-266.

Okwuashi, O., McConchie, J., Nwilo, P. \& Eyo, E. (2008). The challenge of urbanization. Proceedings of DevNet Conference, Wellington, New Zealand.

Oyeniyi, B. (2013). Internal migration in Nigeria: a positive contribution to human development. ACP Observatory on Migration: Research Report ACPOBS/2013/PUB01.

Porio, E. (2009). Urban transition, poverty, and development in the Philippines: a preliminary draft. London: International Institute for Environment and Development.

Potts, D. (2012a). Challenging the myths of urban dynamics in sub-Saharan Africa: the evidence from Nigeria. World Development, 40(7), 1382-1393.

Potts, D. (2012b). Whatever happened to Africa's rapid urbanisation? Africa Research Institute Counterpoints. London: Africa Research Institute.

Preston, S. (1979). Urban growth in developing countries: a demographic reappraisal. Population and Development Review, 5(2), 195-215.

Quigley, J. (2009). Urbanization agglomeration and economic development. In M. Spence, P. Annez, \& R. Buckley (Eds.), Urbanization and growth: commission on growth and development (pp. 115-132). Washington, DC: World Bank.

Rahman, M. (1987). An improvement of the national growth rate method for estimation of internal migration. Bangladesh Development Studies, 15(2), 113-119.

Rahman, M. (2013). Estimation of internal migration by the national growth rate method: an alternative approach. Bangladesh Development Studies, 36(3), 79-87.

Shryock, H., Siegel, J., \& Larmon, E. (1971). The methods and materials of demography (Vol. 2). United States: Bureau of the Census.

Siegel, J., \& Swanson, D. (2004). The methods and materials of demography (second ed.pp. 493-522). London: Elsevier Academic Press.

Skeldon, R. (1990). Population mobility in developing countries. London: Belhaven Press.

Smythe, H. (1960). Urbanization in Nigeria. Anthropological Quarterly, 33(3), 143-148.

Songsore, J. (2009). The urban transition in Ghana: urbanization, national development and poverty reduction. Working paper. London: International Institute for Environment and Development.

The Economist. (2015). Special report Nigeria: opportunity knocks. June 20.

The Guardian. (2017). They came while we were asleep: Lagos residents tell of brutal evictions. Available at: https:/www.theguardian.com/cities/2017/may/31/destroyed-community-lagos-nigeria-residents-forcedevictions-demolitions. Accessed 1 November 2017.

Thompson, W. (1929). Population. American Journal of Sociology, 34(6), 959-975.

Todaro, M., \& Smith, S. (2012). Economic development (11th ed.pp. 269-358). Boston: Pearson.

Turok, I., \& McGranahan, G. (2013). Urbanization and economic growth: the arguments and evidence for Africa and Asia. Environment and Urbanization, 25(2), 465-482.

Turok, I., \& Parnell, S. (2009). Reshaping cities, rebuilding nations: the role of national urban policies. Urban Forum, 20, 157-174.

United Nations. (1974). Manual VIII. methods for projections of urban and rural populations. ST/ESA/SER.A/ 55. Department of Economic and Social Affairs. New York: United Nations.

United Nations. (2001). The components of urban growth in developing countries. ESA/P/WP.169. New York: Population Division Department of Economic and Social Affairs.

United Nations. (2013). World population policies. ST/ESA/SER.A/341. In Department of Economic and Social Affairs, Population Division. New York: United Nations.

United Nations. (2014). World urbanization prospects ST/ESA/SER.A/366. In Department of Economic and Social Affairs. New York: United Nations Accessed 1 October 2017.

United Nations. (2016). Human development report 2016: Human development for everyone. New York: United Nations Development Programme.

Wang, J., \& Maduako, I. (2018). Spatio-temporal urban growth dynamics of Lagos Metropolitan Region of Nigeria based on hybrid methods for LULC modeling and prediction. European Journal of Remote Sensing, 51(1), 251-265.

World Bank. (2016). From oil to cities: Nigeria's next transformation. In Directions in development: countries and regions. Washington, DC: World Bank Group.

World Bank. (2017). World development indicators. In World Bank open data. Washington DC: World Bank Accessed at: http://data.worldbank.org/. Accessed 1 October 2017. 